\title{
Anti-obesity Effect of Black Vinegar Fermented with Herbal Extracts
}

\author{
Dongsub Lee ${ }^{1}$ and Sangwook Park ${ }^{2, \dagger}$ \\ ${ }^{1}$ Department of Healthcare and Biotecnology, College of Aeroservice, Kyungwoon University, Gumi 39160, Korea \\ ${ }^{2}$ Department of Biomedical Laboratory Science, College of Health and Nurse, \\ Kyungwoon University, Gumi 39160, Korea
}

\begin{abstract}
Vinegar has been widely produced for a variety of industrial and domestic use as well as medicinal use. For sale of the commercial vinegar with herbal extracts, we produced an experimental black vinegar through sequential fermentation of alcohol, followed by acetic acid according to the manufacturer's procedure. To investigate the effect of anti-obesity of black vinegar on biochemical values, we evaluated enzyme activities via acetyl-CoA carboxylase (ACC), which plays a critical role in the lipid metabolism. We found that increased phosphorylated adenosine monophosphate (AMP) activated protein kinase (AMPK) and ACC in L6 mouse muscle cells treated with the manufactured vinegar. Based on the results, supplementation of experimental herbal black vinegar inactivates ACC, enhancing the phosphorylation of AMPK. Thus, the lipid oxidation and inhibitory effect of fatty acid synthesis by the black vinegar expects to facilitate the anti-obesity activity.
\end{abstract}

Key Words: Black vinegar, Anti-obesity, AMP activated protein kinase, Acetyl-CoA carboxylase

식초는 일반음식을 오래 보관하기 위한 보존제나 음식 에 직접 곁들여서 먹을 수 있는 양념으로 애용되어 왔으 며, 세계 여러 문화권에서는 음료수로써 시장에서 쉽게 구해서 직접 식초물을 마시기도 한다. 역사적으로 식초를 이용하여 통증완화제로 사용되기도 하였고(Rund et al., 1996; Johnston and Gaas, 2006) 상처를 치료하기 위해 의학 적으로 사용되기도 하였다(Budak et al., 2014). 또한 중국 기록에 의하면 감염을 예방하기 위해 손 소독제로도 사 용한 기록이 있다(Chan et al., 1994; Ho et al., 2017). 18세기 미국의사들이 위장병, 부종과 고열을 치료하기 위해 광범 위하게 식초를 사용했다(Ho et al., 2017). 미국 Food and Drug Administration (FDA) 식품의약품법에 식초에 대한 명 확한 정의는 명시되어 있지 않지만 식초는 과일을 이용하 여 알코올을 발효한 후 이어서 초산 발효를 통해 만들어
진다고 정의하고 있으며 $100 \mathrm{~mL}$ 당 초산이 $4 \mathrm{~g}$ 을 초과하 지 않아야 자연 식초로써 인정하고 있다. 반면에 우리나 라 식품의약품안전처(Ministry of Food and Drug Safety, MFDS) 발행 식품공전에는 식초 생산에 대한 표준이 다음 과 같이 명시되어 있다. 곡물, 과일 또는 알코올 음료를 발효하여 양조하거나 또는 곡물을 당화시킨 용액과 섞어 발효시키거나 음료수로 빙초산 또는 초산만을 희석하여 제조한 합성 식초를 말한다(Baek et al., 2015). 식초를 만 들기 위해서는 두 가지 생물공학적 공정이 필요한데, 무 산소성 상태에서 효모에 의한 알코올 발효(Saccharomyces cerevisiae)와 산소성 상태의 초산 발효(Acetobacter 세균)에 의해 생산된다. 알코올 발효는 당을 알코올로 변화시키는 반면에 초산 발효는 변화된 알코올을 아세트산으로 변화 시켜 줌으로써 식초의 전형적인 시큼한 맛을 만들어 낸다.

* Received: October 20, 2017 / Revised: November 11, 2017 / Accepted: November 13, 2017

†Corresponding author: Sangwook Park. Department of Biomedical Laboratory Science, College of Health and Nurse, Kyungwoon University, Gumi 39160, Korea.

Tel: +82-54-479-1282, Fax:+82-54-479-1280, e-mail: spark367@ikw.ac.kr

(C) The Korean Society for Biomedical Laboratory Sciences. All rights reserved.

(C) This is an Open Access article distributed under the terms of the Creative Commons Attribution Non-Commercial License (http://creativecommons.org/licenses/by-nc/3.0/) which permits unrestricted non-commercial use, distribution, and reproduction in any medium, provided the original work is properly cited. 
원재료와 발효방식에 따라서 식초의 이름을 명명하는데, 발사믹 식초, 와인 식초, 토마토 식초, 대나무 식초, 흑초 등이 그 예이다. 그 중 흑초는 다른 식초 성분보다 유기산 과 아미노산이 풍부하여(Nishidai et al., 2000; Beh et al., 2017), 건강음료로 인식되고 있으며 실제로 지방세포(Chou et al., 2015)의 크기를 줄여주거나 항산화 효과(Tong et al., 2010; Choi et al., 2015)가 있는 것으로 보고되고 있다. 최근 연구 결과에 의하면 폴리페놀과 비타민 등과 같은 생물활성 성 분이 항산화 효과를 나타냄으로써 퇴행성 뇌질환(Pandey and Rizvi, 2009; Seo et al., 2010)의 발생을 줄일 수 있다는 연구도 소개되어 식초에 대한 다양한 연구가 필요할 것 으로 생각한다. 본 연구에서는 한약재로 만든 한방 흑초 의 항비만 효과에 미치는 요소가 무엇인지 확인하고자 하 였다. 발효 조건을 최적화 하기 위해 원료의 당도에 대한 조건을 검토하였다. 효모균에 의해 식초 발효에 충분한 알 코올을 생산하기 위하여 현미당화액 당도를 달리하여 최 적 당도를 검토한 결과, 당류의 함량이 20 brix 미만일 경 우에는 조성물에서 충분한 알코올 발효를 일으키기 힘들 고, 55 brix를 초과할 경우에는 첨가하는 양에 비하여 더 이상 알코올 발효가 증가하지 않음을 확인함으로서 최적 현미당화액과 처방 한약재 발효액이 혼합된 조성물의 당 도를 55 brix로 결정하였다(data not shown). 1차 발효를 위 해, 한약재 복합 추출액은 약 10 20 부피\%, 현미당화액은 20 40 중량 $\%$ 범위에서 최적 혼합 조건을 검토하였으며, 특히 한약재 복합 추출액 15 부피 $\%$ 와 현미 당화액을 30 중량 $\%$ 로 혼합하여 최종 $55 \mathrm{brix}$ 를 맞춘 경우 1 차 알코올 발효에 가장 유리하다는 결과를 도출하였다.

본 연구에서는 다이어트 관련 식용 가능한 한방 소재의 복합 처방전을 도출하고, 이러한 한방 소재를 열수추출 및 복합 발효 조건 최적화를 통한 한방재료 처방 흑초 생산 을 확립하여, 항비만 효능 평가를 통해 기존 감식초 대비 흑초를 연구개발하기 위해 항비만 관련 효능을 먼저 평가 하였다. 현재 식품의약품안전처 기준 식용으로 분류되어 있는 한약재를 기준으로 비만에 효과가 있는 것으로 알려 진 한약재 조합을 통하여 최적 처방전과 혼합비를 도출 하였다: 강황 $100 \mathrm{~g}$, 율무 $100 \mathrm{~g}$, 결명자 $100 \mathrm{~g}$, 백지 $150 \mathrm{~g}$, 당귀 $300 \mathrm{~g}$, 현삼 $150 \mathrm{~g}$ (물 $3 \mathrm{~L}$ 기준). 한약재료 처방전 발 효 전처리 공정에서 율무, 당귀, 강황, 결명자, 백지 및 현 삼 등의 한방 원료 전처리 및 발효공정을 위하여 원료의 당도 조절 및 발효, 후공정 조건을 최적화하였다. 본 연구 에 사용한 한방 발효 흑초 생리활성 성분 분석결과, 한방 발효 흑초의 초산 함량은 $4.9 \%$ 로 낮았지만 식품공전의
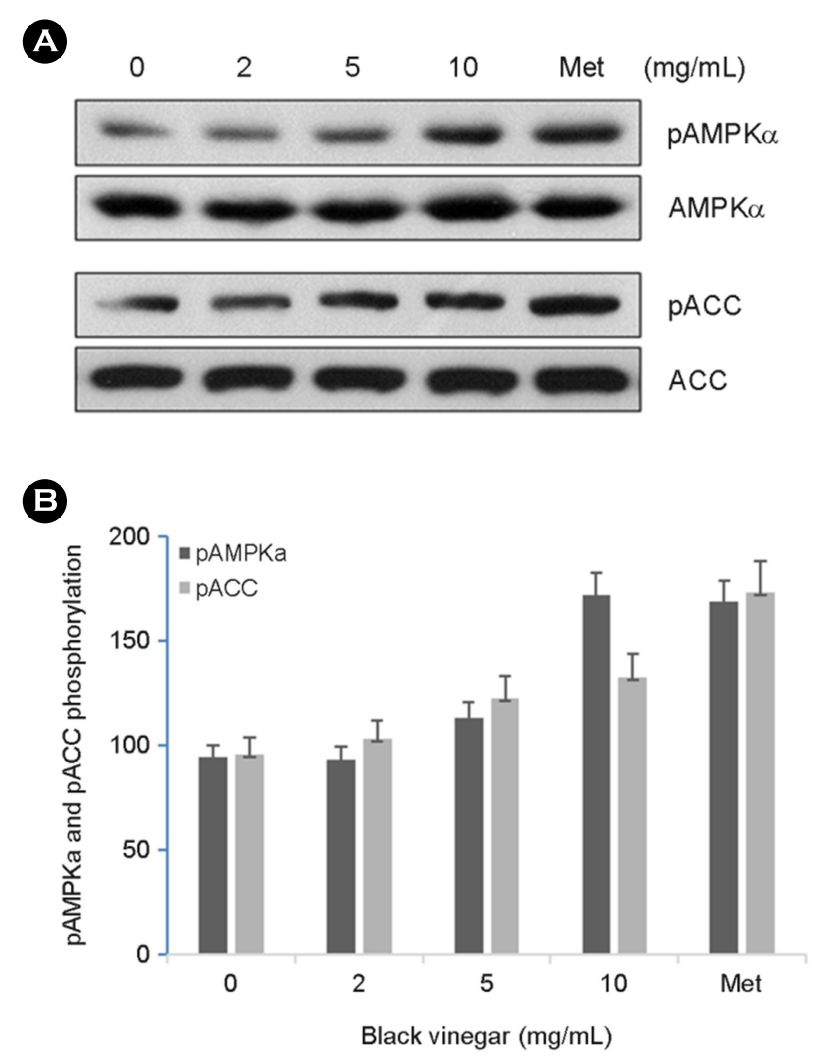

Fig. 1. The phosphorylation of pAMPKa and pACC. (A) Representative immunoblots showing phospho-AMPK $\alpha$ (upper), phosphor-ACC (lower), and ACC on L6 cell. Dose-dependent black vinegar enhances the phosphorylation of AMPK $\alpha$ and ACC. Met, metformin. (B) Ratio of phosphorylation was quantified against $\mathrm{ACC}$, and AMPK $\alpha$.

식초 규격에 적합한 범위에 포함되었다. 총 폴리페놀 함 량을 산출하기 위해서 표준계산식을 이용하여 $1 \mathrm{~N}$ Folinciocalteu 시약 $0.2 \mathrm{~mL}$ 과 시료 $0.1 \mathrm{~mL}$ 을 첨가 후 진탕한 후 1 분간 실온에서 반응시켰다. $20 \% \mathrm{Na}_{2} \mathrm{CO}_{3} 3 \mathrm{~mL}$ 을 다시 첨가하여 진탕한 후 2시간 실온에서 방치 후 $765 \mathrm{~nm}$ 흡 광도로 측정하였다. 본 한방 발효 흑초의 폴리페놀 함량 은 $233.36 \mathrm{ppm}$ 으로 분석되어 기존 제품(감현미 복합 식초 $109.21 \mathrm{ppm}$ )에 비해 2.1배 높은 값을 나타내어 생리활성 이 풍부한 발효 식초임을 알 수 있었다. 본 연구에서는 한 약재로 만든 한방 흑초의 항비만 효과에 미치는 요소가 무엇인지 확인하고자 하였다. 한방 흑초에 의해서 adenosine monophosphate (AMP) activated protein kinase (AMPK) 가 활성화되어 인산화가 증가하면 지질대사에 긍정적인 대사효과에 영향을 미치는 데, 이 과정에서 acetyl-CoA carboxylase (ACC)의 인산화가 일어나게 되고 상대적으로 
$\mathrm{ACC}$ 는 비활성화되어 지질형성을 억제한다. $\mathrm{ACC}$ 는 간, 근 육 등의 조직에서 지질대사를 조절하는 중요한 효소이며, Acetyl-CoA를 malonyl-CoA로 탄산화시키는 작용을 한다. 이 때, malonyl-CoA는 미토콘드리아의 외막에 존재하는 Carnitine palmitoyltransferase-1 (CPT-1)의 저해제로 작용한다. CPT-1의 기능은 생체 내에서 지방산화를 촉매하는 역할 을 하는 데 긴사슬 지방산을 미토콘드리아 내부로 이동시 켜 $\beta$-oxidation을 한다. CPT-1의 활성은 미토콘드리아에서 일어나는 지방의 $\beta$-oxidation에 매우 중요한 작용을 한다. 그러므로, $\mathrm{AMPK}$ 의 활성화에 의해 $\mathrm{ACC}$ 의 인산화 $(\mathrm{pACC})$ 가 증진되어 $\mathrm{ACC}$ 효소활성이 억제되면 malonyl-CoA의 생성량이 감소하여 지방산화를 일으킨다. 이에 지방산을 태우는 산화작용에 의해 ATP 생성량이 증가하고 지방산 산화 증가에 의한 체지방 감소에 기여하게 된다.

이러한 효과는 임상치료제로 사용되고 있는 metformin 투여에서도 동일한 효과를 나타내는 데, 지방대사에 영향 을 미치는 triglyceride 등과 같은 지방형성 유전자발현을 억제하는 것으로 알려져 있다. 이를 확인하기 위해 한방 발효 흑초를 처리한 마우스 근육세포, L6 세포주에서 항 비만 관련 표적 효소인 AMPK 활성을 분석하였다(Vytla and Ochs, 2013; Kristensen et al., 2013; Kim et al., 2017). 발효 흑초를 L6 세포에 처리했을 때 농도의존적으로 $\mathrm{AMPK}$ 와 $\mathrm{ACC}$ 의 인산화가 모두 증가되어 $\mathrm{ACC}$ 의 효소활성을 비활 성화 시킴으로써 인산화된 $\mathrm{AMPK}$ 가 현저히 활성화 됨을 알 수 있었다(Fig. 1A), 농도구배별 ACC에 대한 AMPK $\alpha$ 의 인산화 정량분석 비율에서도 $\mathrm{AMPK}$ 가 농도가 증가함 을 알 수 있었다(Fig. 1B). 이러한 결과로, 발효 흑초액이 세포 내 지방의 산화를 촉진하고 지방합성을 억제할 수 있는 효과가 있어 항비만 등을 포함한 대사질환 개선 치 료 기능에 효과가 있을 것으로 기대한다. 향후, 고지방 식 이 마우스를 활용한 항비만 관련 바이오마커를 분석하여 한방 발효 흑초가 고지방 식이로 유도된 마우스의 비만을 억제할 수 있을 것으로 기대하며, 유관 제품활용에 긍정 적인 가치를 제공할 것으로 사료된다.

\section{ACKNOWLEDGEMENTS}

This study was supported by Kyungwoon University domestic grant in 2017.

\section{CONFLICT OF INTEREST}

The authors have no conflicts of interest to disclose.

\section{REFERENCES}

Baek SY, Lee CH, Park YK, Choi HS, Mun JY, Yeo SH. Quality characteristics of fermented vinegar prepared with the detoxified Rhus verniciflua extract. Korean Journal of Food Preservation. 2015. 22: 674-682.

Beh BK, Mohamad NE, Yeap SK, Ky H, Boo SY, Chua JYH, Tan SW, Ho WY, Sharifuddin SA, Long K, Alitheen NB. Antiobesity and anti-inflammatory effects of synthetic acetic acid vinegar and Nipa vinegar on high-fat-diet-induced obese mice. Scientific Reports. 2017. 7: 6664.

Budak NH, Aykin E, Seydim AC, Greene AK, Seydim ZBG. Functional properties of vinegar. Journal of Food Science. 2014. 79: 757-764.

Chan E, Ahmed TM, Wang M, Chan JC. History of medicine and nephrology in Asia. American Journal of Nephrology. 1994. 14: 295-301.

Choi HJ, Gwak KJ, Choi DB, Park JY, Cheong HS. Antimicrobial efficacy of fermented dark vinegar from unpolished rice. Microbiology and Biotechnology Letters. 2015. 43: 97-104.

Chou CH, Liu CW, Yang DJ, Wu YH, Chen YC. Amino acid, mineral, and polyphenolic profiles of black vinegar, and its lipid lowering and antioxidant effects in vivo. Food Chemistry. 2015. 168: 63-69.

Ho CW, Lazim AM, Fazry S, Zaki UKHH, Lim SJ. Varieties, production, composition and health benefits of vinegars: A review. Food Chemistry. 2017. 221: 1621-1630.

Johnston CS, Gaas CA. Vinegar. Medicinal uses and antiglycemic effect. Medscape General Medicine. 2006. 8: 61.

Kim YJ, Park HB, Kim PH, Park JS, Kim KS. Enhanced anticancer efficacy in MCF-7 breast cancer cells by combined drugs of metformin and sodium salicylate. Biomedical Science Letters. 2017. 23: 290-294.

Kristensen JM, Larsen S, Helge JW, Dela F, Wojtaszewski JFP. Two weeks of metformin treatment enhances mitochondrial respiration in skeletal muscle of AMPK kinase dead but not wild type mice. PLOS One. 2013. 8: e53533.

Nishidai S, Nakamura Y, Torikai K, Yamamoto M, Ishihara N, Mori $\mathrm{H}$, Ohigashi $\mathrm{H}$. Kurosu, a traditional vinegar produced from unpolished rice, suppress lipid peroxidation in vitro and in mouse skin. Bioscience Biotechnology Biochemistry. 2000. 64: 1909-1914.

Pandey KB, Rizvi SI. Plant polyphenols as dietary antioxidants in 
human health and disease. Oxidative Medicine and Cellular Longevity. 2009. 2: 270-278.

Rund CR. Nonconventional topical therapies for wound care. Ostomy Wound Management. 1996. 42: 22-24.

Seo HK, Jang SY, Kim HJ, Park HR, Park JH, Ahn GH, Lee SC. Antioxidant activity and neuroprotective effect of concentrates from commercial sweet persimmon wine. Korean Journal of Food and Cookery Science. 2010. 26: 13-17.

Tong LT, Katakura Y, Kawamura S, Baba S, Tanaka Y, Udono M, Kondo Y, Nakamura K, Imaizumi K, Sato Masao. Effects of Kurozu concentrated liquid on adipocyte size in rats. Lipids in Health and Disease. 2010. 9: 134-142.

Vytla VS, Ochs RS. Metformin increases mitochondrial energy formation in L6 muscle cell cultures. The Journal of Biological Chemistry. 2013. 288: 20369-20377.

https://doi.org/10.15616/BSL.2017.23.4.402

Cite this article as: D Lee, S Park. Anti-obesity Effect of Black Vinegar Fermented with Herbal Extracts. Biomedical Science Letters. 2017. 23: 402-405. 